\title{
Sustainable construction in Turkish higher education context
}

\author{
F. Topak ${ }^{1 *}$, O.B. Tokdemir ${ }^{2}$, M.K. Pekeriçli ${ }^{1}$ and A.M. Tanyer ${ }^{1}$ \\ ${ }^{1}$ Middle East Technical University, Department of Architecture, Ankara, Turkey \\ ${ }^{2}$ Middle East Technical University, Department of Civil Engineering, Ankara, Turkey
}

\begin{abstract}
As the construction industry is one of the dominant contributors to the world's total $\mathrm{CO} 2$ emissions and it has huge negative impacts on the environment, sustainable construction has become a key aspiration in the field. Through utilizing eco-friendly design and resource efficiency, sustainable construction is considered as the main concept to create and operate a healthy built environment. Although sustainability has been demonstrated as a timeless objective for continuous development in Turkey's governmental policies, the number of qualified professionals in the field and the attributed significance to the notion of sustainability in the Turkish educational context is questionable. Accordingly, this paper concentrates on the Turkish architectural and civil engineering education - two disciplines that are expected to raise experts on the subject - within the scope of sustainable construction. Ten research universities, which are identified by the Higher Education Institute (YÖK), are analyzed in terms of the content of the curriculum and the conducted graduate studies in architecture and civil engineering departments. The main aim of this paper is to reveal the lack of sustainability-related graduate studies and sustainability-related content in the established curriculum of the higher education institutions in Turkey.
\end{abstract}

\section{Keywords}

Architectural education; Civil engineering education; Sustainability; sustainable construction

Received: 13 January 2019; Accepted: 25 February 2019

ISSN: 2630-5771 (online) @ 2019 Golden Light Publishing All rights reserved.

\section{Introduction}

The construction sector is known to be one of the large-scale consumers of energy, natural resources, and raw materials, and it has various impacts on the environment. A substantial volume of energy is consumed during manufacturing, transportation, and installation of construction materials, as well as in the process of construction activities [1]. According to the data of the Organization for Economic Cooperation and Development (OECD), nearly $40 \%$ of primary energy is consumed by the construction industry in its member states [2]. In the United States, the situation is similar to that of
OECD; $40 \%$ of total energy is used by buildings [3]. Moreover, Uttam (2014) points out the data of the Worldwatch Institute, which demonstrates that construction sector is responsible for $40 \%$ of the world's annual raw materials consumption and more than $25 \%$ yearly wood utilization. Throughout their lifecycle including the construction and demolition, buildings contribute to the $\mathrm{CO} 2$ emissions released in the atmosphere with a share of nearly $50 \%$, creating an enhanced greenhouse effect [5].

The apparent impact of construction on the environment, coupled with concerns over

* Corresponding author

Email: ftopak@metu.edu.tr 
operational efficiency, government regulations, potential cost savings and competitive advantages for companies, have led the industry towards an approach, namely sustainable construction, where sustainable development principles are applied to the building lifecycles with a holistic understanding. One of the first definitions of the term sustainable development was mentioned in the Bruntland Report in 1987 as "development that meets the needs of the present without compromising the ability of future generations to meet their own needs" [6]. When evaluated within the perspective of this very first definition of sustainable development, the main principle for sustainable construction to follow can be interpreted as using resources efficiently in both construction and operation phases of buildings, while enhancing an ecologically friendly built environment. This principle requires a paradigm shift in the construction sector that will both increase the effectiveness of work processes in the field and contribute to the issues concerning the protection of the environment, social well-being, and economic issues. It is clear to infer that, if a change towards a sustainable approach is intended in the way business is carried out and the way people work, sustainability should be integrated into the educational context to raise skilled professionals on the subject. This study demonstrates the current situation of sustainable construction in civil engineering and architecture education in Turkey.

\section{Sustainable construction}

The interest in sustainable development has shown a substantial increase since the publication of the Bruntland Report [6], and in general, sustainability has been attributed to generating solutions for lessening the negative effects of human behavior on the environment. As the construction industry is known as a major consumer of non-renewable resources, a sizeable source of waste and a largescale contributor to the world's total $\mathrm{CO} 2$ emissions, it has a huge negative environmental impact, and it is recognized as a dominant threat for sustainable development. In order to minimize and eliminate the impact of the construction industry, escalating construction activities' sustainability has become a fundamental aspiration [7].

Along with the environmental concerns, there are many drivers of sustainability in construction mentioned in the literature, such as customer requirements, competitive advantages, cost savings, operational efficiency, government regulations and company strategy for long-term survival in business [8]. Yet, sustainable construction is most comprehensively associated with the ecological, social and economic issues of a building in the context of its community [9]. The goal of sustainable construction was defined for the first time by The Conseil International du Batiment (CIB), an international construction research network, as "creating and operating a healthy built environment based on resource efficiency and ecological design" in 1994 [10]. With the intention of informing decision making during each phase of building's entire life cycle, seven principles for sustainable construction was articulated by CIB.

As shown in Fig. 1, principles of sustainable construction apply throughout the entire building lifecycle, from the planning process to the demolition (referred to as deconstruction in the framework). It promotes the efficient use of resources in the design, construction, and operation of buildings while providing an ecologically friendly and healthy built environment and reducing the lifecycle costs. All resources that are required to construct, operate and maintain the built environment, including land, materials, water, energy, and ecosystems are encompassed by the principles. With the employment of these principles, initial construction costs could be decreased, and recycling of construction materials reduces the amount of physical waste generated in a project, as well as the amount of pollution associated with the processes [11].

Balancing the rational harmony between social, environmental and economic components of sustainable construction is an important goal. Environmental sustainability refers to the protection of natural systems and ecological balance, whereas economic sustainability refers to 


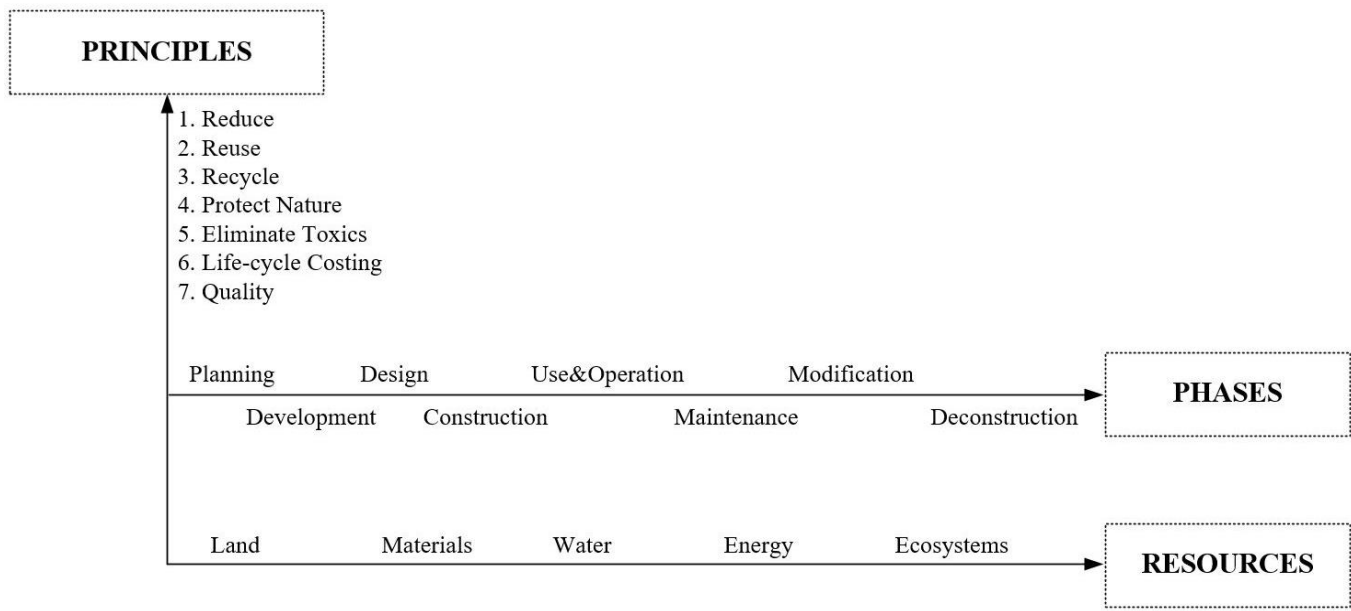

Fig. 1. Framework for sustainable construction (Adapted from CIB (1994))

the provision of a steady investment flow with efficient use of resources, and social sustainability is related with supplying fundamental human rights and freedom for everyone in an equal manner [12]. According to Luther (2005), as referred in Ogunbiyi (2014), if the necessary steps are taken towards sustainable development through achieving the synergy in the construction industry, the communities will benefit from a range of positive environmental, economic and social changes. These benefits include improved air and water quality, decreased energy consumption and waste disposal, decreased operating and maintenance costs, improved health and occupant comfort, degraded liability, and enhanced life quality.

In order to achieve the successful implementation of sustainability in construction, there are various matters to be considered. According to the paper of Huovila \& Koskela (1998), where the variability of the current sustainable construction practices in different countries is pointed out, while the mature economies prioritize enlarging their sustainable building stock by either refurbishment or new construction, transition economies are after establishing new developments that will reduce the housing shortage and improve their networks of transportation. On the other hand, in developing economies, the top priority is to create jobs in the construction sector for citizens. It can be inferred from this assertion that implementation priorities of sustainable construction practices are influenced by the socio-economic advancement level of the context. Therefore, the construction industry should be more inclusionary in adopting sustainable developments by considering all the issues that are valued by societies, and driven by a mixture of social, environmental and economic forces.

\section{Vision towards sustainable construction}

Turkey, as a developing country, has also included sustainable development in the objectives of "The Tenth Development Plan," and demonstrated the green growth as an important target. Within the scope of the development plan, protecting the environment, increasing competitiveness with ecoefficient production, sustainable use of resources and attaining sustainable supply-demand chain in the industry are all listed amongst the nation's targets [15]. In order to achieve sustainability in both the local and the global context, raising the consciousness about sustainable development, and reevaluation of the work processes in the construction sector is crucial, as explained above. Accomplishing this shift in the industry could be led by the professions of civil engineering and architecture. American Society of Civil Engineers (ASCE) published a report called "The Vision for Civil Engineering in 2025", in which a reinvention of outlook, image, and service delivery for the discipline is foreseen [16]. Accordingly, the vision requires the global civil engineering profession to 
recognize the resource depletion reality, the issue of social equity in resource consumption and the need for sustainable design and construction.

ASCE (2006) emphasizes the importance of education in developing skilled professionals for reaching the vision goals of 2025 and highlights the need for reassessment of the current curriculum in civil engineering departments. Similarly, sustainable development is promoted in the curriculum of educational facilities in many OECD members [17]. According to the requirements of the Accreditation Board for Engineering and Technology (ABET), an international accreditation institution for universities, sustainability is given as a program criterion for both architectural and civil engineering departments. For architecture departments, ABET requires program graduates to have a capability of considering fundamental attributes of building performance and sustainability in the design level, whereas, for civil engineering, graduates should have the skill of designing a system, component or process within the principles of sustainability [18].

\section{Sustainable Construction within the Curriculum of Turkish Research Universities}

In 2017, the Higher Education Council (YÖK, in Turkish) acknowledged 10 Turkish colleges as research universities, namely Ankara University, Boğaziçi University, Erciyes University, Gazi University, Gebze Technical University, Hacettepe University, İstanbul University, İstanbul Technical University, İzmir Institute of Technology and Middle East Technical University. In addition to selected research universities, five institutions were identified as future candidates; namely, Çukurova University, Ege University, Selçuk University, Uludă̆ University, and Yıldız Technical University. All these universities were selected to pioneer the scientific and technological advancements and help the educational and industrial development of the country systematically. In this study, architectural and civil engineering departments of the aforementioned ten research universities were assessed within the scope of sustainable construction. Available data about the undergraduate and graduate education in the websites of research universities and related graduate studies in YÖK database were collected. Accordingly, İstanbul Technical University (ITTU), Middle East Technical University (METU) and Gazi University are leading the graduate studies in sustainable construction, while there are no recorded thesis or dissertations for five research universities (Fig. 2) [19]. Here, it is worth mentioning that, despite not being selected as one of the ten primary research universities, Yildiz Technical University has 12 graduate studies related with sustainability in YÖK database, which place them as third best within this context in Turkey. Although there is an increasing trend in graduate studies as shown in Fig. 3, sustainable construction in Turkey can still be considered as an undiscovered research subject, considering the nonexistence or lack of researches in the pioneering institutions.

After reviewing the graduate studies, the contents of the curriculum in referred research universities were investigated. Among the research universities, Ankara, Boğaziçi, Hacettepe, and İstanbul do not have an architecture department, while civil engineering departments appear in all, except Ankara University (Table 1). The websites of the currently available departments are scanned, and it is observed that ITU is in a leading position in the number of sustainable construction-related courses that are integrated within the curriculum of the Department of Architecture. METU is in a follow-up position, with provided undergraduate and graduate elective courses in both civil engineering and architecture departments. As shown in Table 1, when compared with architecture departments, sustainability content in civil engineering departments clearly lacks in the research universities. Apart from İTU and METU, no related courses in other universities' civil engineering curriculum are observed. Moreover, since most of the courses demonstrated in Table 1 are electives, it can be noted that sustainable construction is not seen as an important component of the educational spine in neither architecture nor civil engineering departments. 
In order to detect where leading universities in Turkey stand in terms of sustainable construction education in the world, the curriculum of architecture and civil engineering departments of Princeton University, which is the top ranking institution in the United States [20], were reviewed. It is noticed that there are two courses related to sustainability in each department of Princeton, as shown in Table 2 (Princeton University, 2018). Accordingly, although research universities cannot be claimed as satisfactory in an overall consideration, İTU and METU are standing in a close line with high-ranking universities within the scope of sustainable construction education.

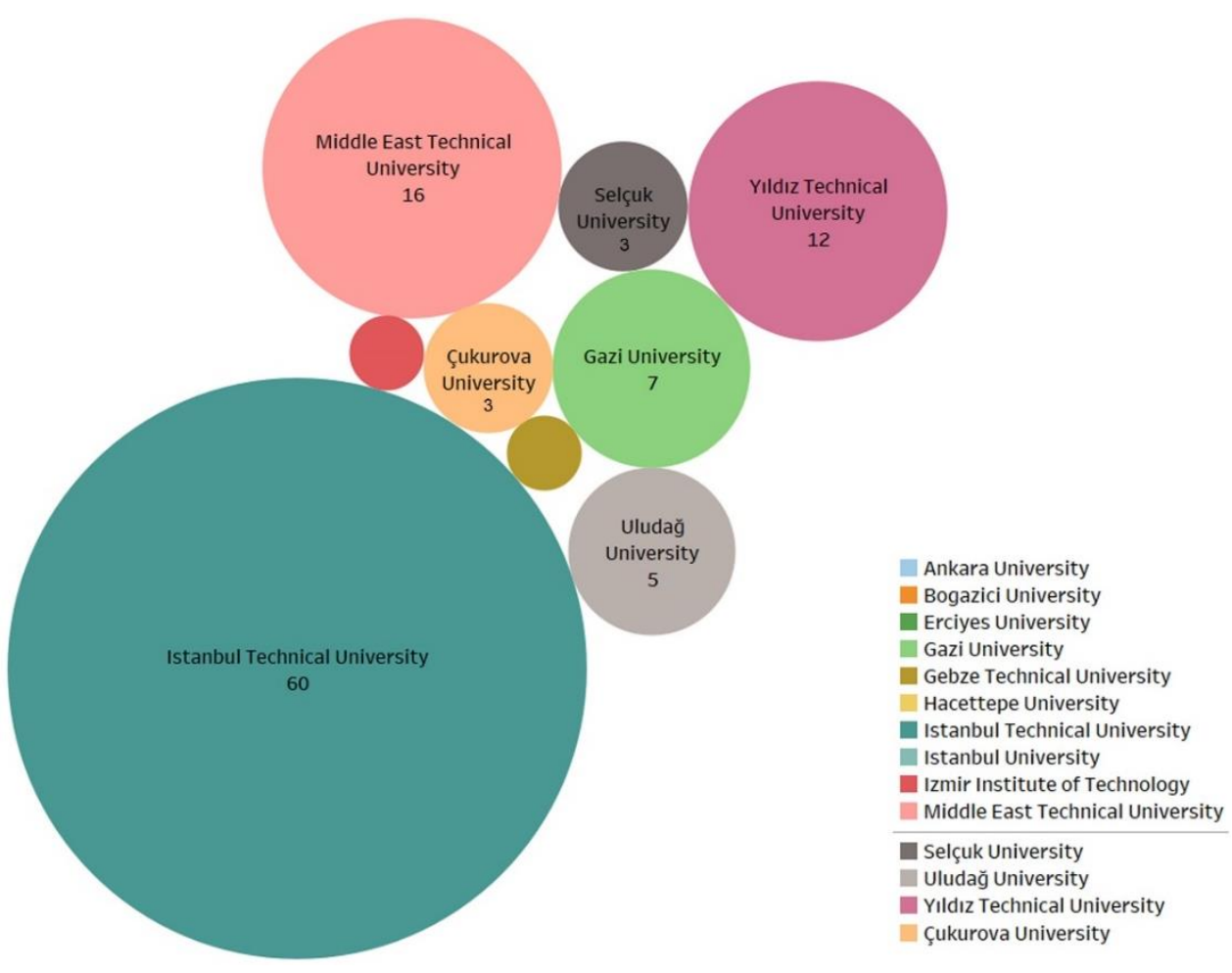

Fig. 2. Number of conducted graduate studies on sustainability in research universities and candidates

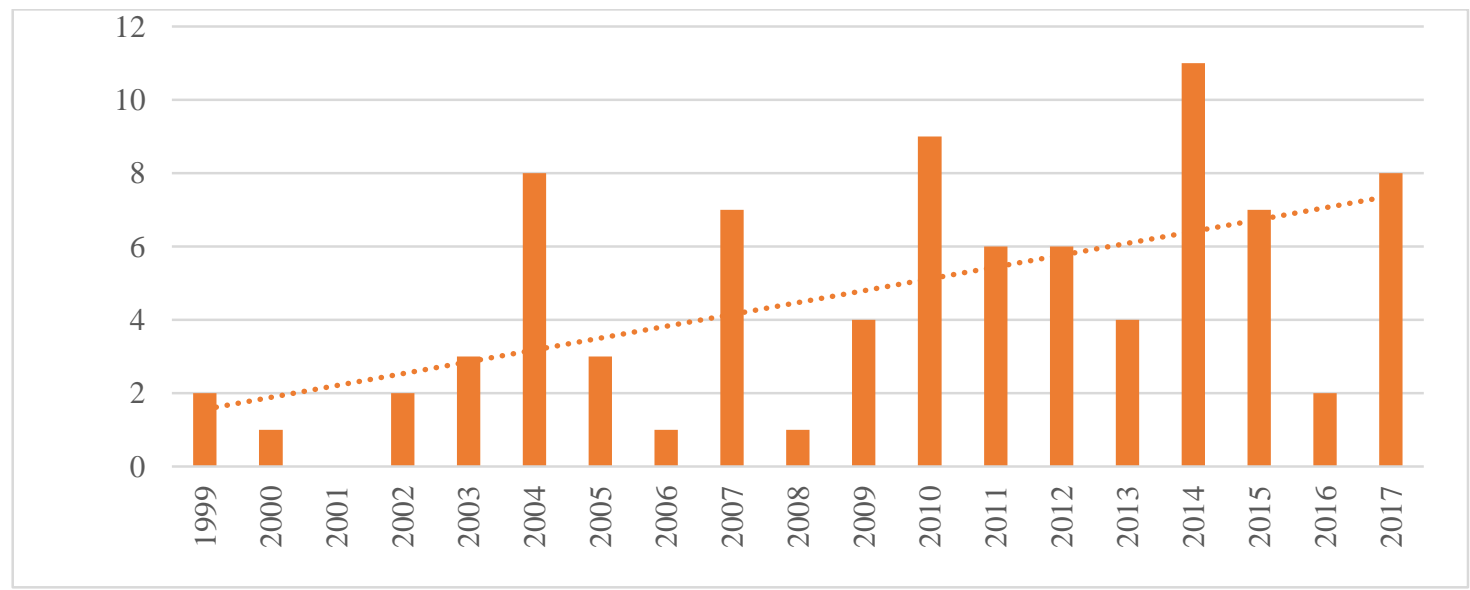

Fig. 3. Number of conducted graduate studies on sustainability throughout the years 
Table 1. Courses on sustainability in Turkish research universities

\begin{tabular}{|c|c|c|c|}
\hline University & Department & Courses & Category \\
\hline \multirow{2}{*}{$\begin{array}{l}\text { Ankara } \\
\text { University }\end{array}$} & Civil Engineering & Department is not established. & \\
\hline & Architecture & Department is not established. & \\
\hline \multirow{2}{*}{$\begin{array}{l}\text { Boğaziçi } \\
\text { University }\end{array}$} & Civil Engineering & No course is relevant. & \\
\hline & Architecture & Department is not established. & \\
\hline \multirow{3}{*}{$\begin{array}{l}\text { Erciyes } \\
\text { University }\end{array}$} & Civil Engineering & No course is relevant & \\
\hline & Architecture & MIM S124 Introduction to Sustainable Design & $\begin{array}{l}\text { Undergraduate } \\
\text { Compulsory }\end{array}$ \\
\hline & & MİM S66 Simulation Software in Sustainable Design & Graduate Elective \\
\hline \multirow{2}{*}{$\begin{array}{l}\text { Gazi } \\
\text { University }\end{array}$} & Civil Engineering & No course is relevant & \\
\hline & Architecture & 5201355 - Social Sustainability in Architecture & Graduate Elective \\
\hline \multirow{3}{*}{$\begin{array}{l}\text { Gebze } \\
\text { Technical } \\
\text { University }\end{array}$} & Civil Engineering & $\begin{array}{l}\text { No access to undergraduate courses. No course is } \\
\text { relevant in the graduate level. }\end{array}$ & \\
\hline & Architecture & ARCH 144 Theory of Sustainable Design & $\begin{array}{l}\text { Undergraduate } \\
\text { Compulsory }\end{array}$ \\
\hline & & ARCH 643 Environmental Building Design & Graduate Elective \\
\hline \multirow{2}{*}{$\begin{array}{l}\text { Hacettepe } \\
\text { University }\end{array}$} & Civil Engineering & No course is relevant. & \\
\hline & Architecture & Department is not established. & \\
\hline \multirow[t]{2}{*}{$\begin{array}{l}\text { İstanbul } \\
\text { University }\end{array}$} & Civil Engineering & $\begin{array}{l}\text { No course name is relevant. No course description is } \\
\text { available. }\end{array}$ & \\
\hline & Architecture & Department is not established. & \\
\hline \multirow{6}{*}{$\begin{array}{l}\text { İstanbul } \\
\text { Technical } \\
\text { University }\end{array}$} & Civil Engineering & YIP515E - Sustainable Construction & Graduate Elective \\
\hline & Architecture & MIM431E - Construction Project & $\begin{array}{l}\text { Undergraduate } \\
\text { Compulsory }\end{array}$ \\
\hline & & $\begin{array}{l}\text { PYY524E - Project Management for Sustainable } \\
\text { Construction Projects }\end{array}$ & Graduate Elective \\
\hline & & MTS539 - Sustainable Transformation and Architecture & Graduate Elective \\
\hline & & CKY550E - Building Technology: Sustainability & Graduate Elective \\
\hline & & $\begin{array}{l}\text { CKY539 - Environmental Sustainability Assessment in } \\
\text { Building Elements }\end{array}$ & Graduate Elective \\
\hline \multirow{3}{*}{$\begin{array}{l}\text { İzmir } \\
\text { Institute of } \\
\text { Technology }\end{array}$} & Civil Engineering & No course is relevant. & \\
\hline & Architecture & $\begin{array}{l}\text { AR } 482 \text { - Building Performance Simulation for } \\
\text { Sustainable Design }\end{array}$ & $\begin{array}{l}\text { Undergraduate } \\
\text { Elective }\end{array}$ \\
\hline & & AR 571 Sustainable Architecture & Graduate Elective \\
\hline \multirow{4}{*}{$\begin{array}{l}\text { Middle } \\
\text { East } \\
\text { Technical } \\
\text { University }\end{array}$} & Civil Engineering & $\begin{array}{l}\text { CE7011 - Sustainability and Life Cycle Assessment of } \\
\text { Civil Engineering Structures }\end{array}$ & Graduate Elective \\
\hline & & $\begin{array}{l}\text { CE4005 - Green Building Materials for Sustainable } \\
\text { Construction }\end{array}$ & $\begin{array}{l}\text { Undergraduate } \\
\text { Elective }\end{array}$ \\
\hline & Architecture & ARCH326-Architecture in Situ & $\begin{array}{l}\text { Undergraduate } \\
\text { Elective }\end{array}$ \\
\hline & & $\begin{array}{l}\text { BS583- Sustainability in Construction: Concepts and } \\
\text { Technologies }\end{array}$ & Graduate Elective \\
\hline
\end{tabular}


Table 2. Courses on sustainability in the top ranking university of the United States

\begin{tabular}{llll} 
Princeton & Civil Engineering & CEE 334 - Global Environmental Issues & Undergraduate Elective \\
University & & CE477 - Engineering Design for Sustainable & Graduate Elective \\
& & Development & \\
& ARCH 208 Designing Sustainable Systems & Undergraduate Elective \\
& ARC 514- The Environmental Engineering of & Graduate Elective \\
& Buildings & \\
\hline
\end{tabular}

\section{Conclusions}

Due to the fact that overcoming the challenges originated by climate change, loss of biodiversity, limited water resources, global health issues, and extreme poverty requires equipped professionals with necessary skills, knowledge, and background; higher education has a crucial role for ensuring a more sustainable future. Providing a comprehensive sustainability education for construction practitioners is vital for achieving a well-grounded transformation in the sector. Higher education community should encourage young researchers to carry out studies for clarifying the requirements and bottlenecks of the industry for a paradigm shift, as well as increasing the public awareness towards sustainable construction to push compelling governmental policies and regulations in the field. Once the foundations for enhancing a more sustainable future is laid in the educational context, the conceivable obstacles in the industry can be more easily resolved. For this to happen in a national context, research universities in Turkey need to lead the way, as they are expected. The curriculum of architectural and civil engineering departments should be reevaluated and adjusted to scale up the education for sustainable construction. Raising young professional with a broader understanding of sustainability, together with supervising them towards having experience in the current professional life to instill "improvable" practice should be one of the main concerns of these institutions. ITU and METU are seen to have similar sustainability-related content integration with the world's mostly regarded universities in aforementioned two disciplines. However, according to the report of Association for the Advancement of Sustainability in Higher Education [22], there is still a long list of actions to be taken in higher education context for a paradigm shift towards more sustainable industries, which could be rationalized with collaborative summits between higher education community, state agencies, sustainability NGOs and students.

\section{References}

[1] Yan H, Shen Q, Fan LCH, Wang Y, Zhang L (2010) Greenhouse gas emissions in building construction: A case study of One Peking in Hong Kong. Building and. Environment 45: 949-955. doi:10.1016/j.buildenv.2009.09.014.

[2] OECD, Environmentally Sustainable Buildings: Challenges and Policies, OECD Publications Service, Paris, France, 2003.

[3] DOE, Building energy data book, US Department of Energy, 2011.

[4] Uttam K. Seeking Sustainability in the Construction Sector: Opportunities within Impact Assessment and Sustainable Public Procurement, Royal Institute of Technology, 2014.

[5] Dimoudi A, Tompa C (2008) Energy and environmental indicators related to construction of office buildings. Resources, Conservation and Recycling 53: 86-95.

[6] Bruntland GO. Our Common Future, Rep. 1987 World Comm. Environ. Dev. (1987).

[7] Aigbavboa C, Ohiomah I, Zwane T (2017) Sustainable construction practices: "a lazy view" of construction professionals in the South Africa construction industry. Energy Procedia. 105: 3003 3010. doi:10.1016/j.egypro.2017.03.743.

[8] Ogunbiyi O. Implementation of the Lean Approach in Sustainable Construction: A Conceptual Framework, Lancashire, Central, 2014.

[9] Kibert CJ. Introduction to Sustainable Construction, In: Sustain. Constr. Green Build. Des. Deliv., 2016, pp. 1-18.

[10] CIB, Sustainable Construction, in: First Int. Conf. Sustain. Constr., Tampa, Florida, 1994.

[11] Forbes L. Sustainability and Lean Construction, Thought Leadersh. Process Improv. (2014). https://the-lmj.com/2014/12/sustainability-andlean-construction/.

[12] Yılmaz M, Bakış A (2015) Sustainability in Construction Sector. Procedia-Social and Behavioral Sciences 195: 2253-2262. 
[13] Luther R. Sustainable Construction-Planning for Our Future, Constr. Technol. Cent. Atl. (2005).

[14] Huovila P, Koskela L. Contribution of the principles of lean construction to meet the challenges of sustainable development. In: Int. Gr. Lean Constr., 1998: pp. 13-15.

[15] Ministry of Development, The Tenth Development Plan 2014-2018, Ankara, 2014.

[16] ASCE, The Vision for Civil Engineering in 2025, United States, 2006.

[17] OECD, Promoting Sustainable Consumption: Good Practices in OECD Countries, 2008. www.oecd.org/publishing/corrigenda.

[18] ABET, Criteria for Accrediting Engineering Programs, 2015.

[19] YÖK, National Thesis Repository, (2018). https://tez.yok.gov.tr/UlusalTezMerkezi/ (accessed March 9, 2018).

[20] U.S.News, National University Rankings, (2018). https://www.usnews.com/best-

colleges/rankings/national-universities (accessed June 19, 2018).

[21] Princeton University, Course Offerings, (2018). https://registrar.princeton.edu/course-offerings/ (accessed June 19, 2018).

[22] AASHE, Sustainability Curriculum in Higher Education: A Call to Action, 2010. 